\title{
Science to Support the Understanding of Ohio's
} Water Resounces, $2014-15$

\section{Introduction}

Ohio's water resources support a complex web of human activities and nature-clean and abundant water is needed for drinking, recreation, farming, and industry, as well as for fish and wildlife needs. Although rainfall in normal years can support these activities and needs, occasional floods and droughts can disrupt streamflow, groundwater, water availability, water quality, recreation, and aquatic habitats. Ohio is bordered by the Ohio River and Lake Erie; it has over 44,000 miles of streams and more than 60,000 lakes and ponds (State of Ohio, 1994). Nearly all the rural population obtain drinking water from groundwater sources.

The U.S. Geological Survey (USGS) works in cooperation with local, State, and other Federal agencies, as well as universities, to furnish decision makers, policy makers, USGS scientists, and the general public with reliable scientific information and tools to assist them in management, stewardship, and use of Ohio's natural resources. The diversity of scientific expertise among USGS personnel enables them to carry out large- and small-scale multidisciplinary studies. The USGS is unique among government organizations because it has neither regulatory nor developmental authority -its sole product is impartial, credible, relevant, and timely scientific information, equally accessible and available to everyone. The USGS Ohio Water Science Center provides reliable hydrologic and water-related ecological information to aid in the understanding of the use and management of the Nation's water resources, in general, and Ohio's water resources, in particular. This fact sheet provides an overview of current (2014) or recently completed USGS studies and data activities pertaining to water resources in Ohio. More information regarding projects of the USGS Ohio Water Science Center is available at http://oh.water.usgs.gov/.

\section{Understanding of Ohio's}

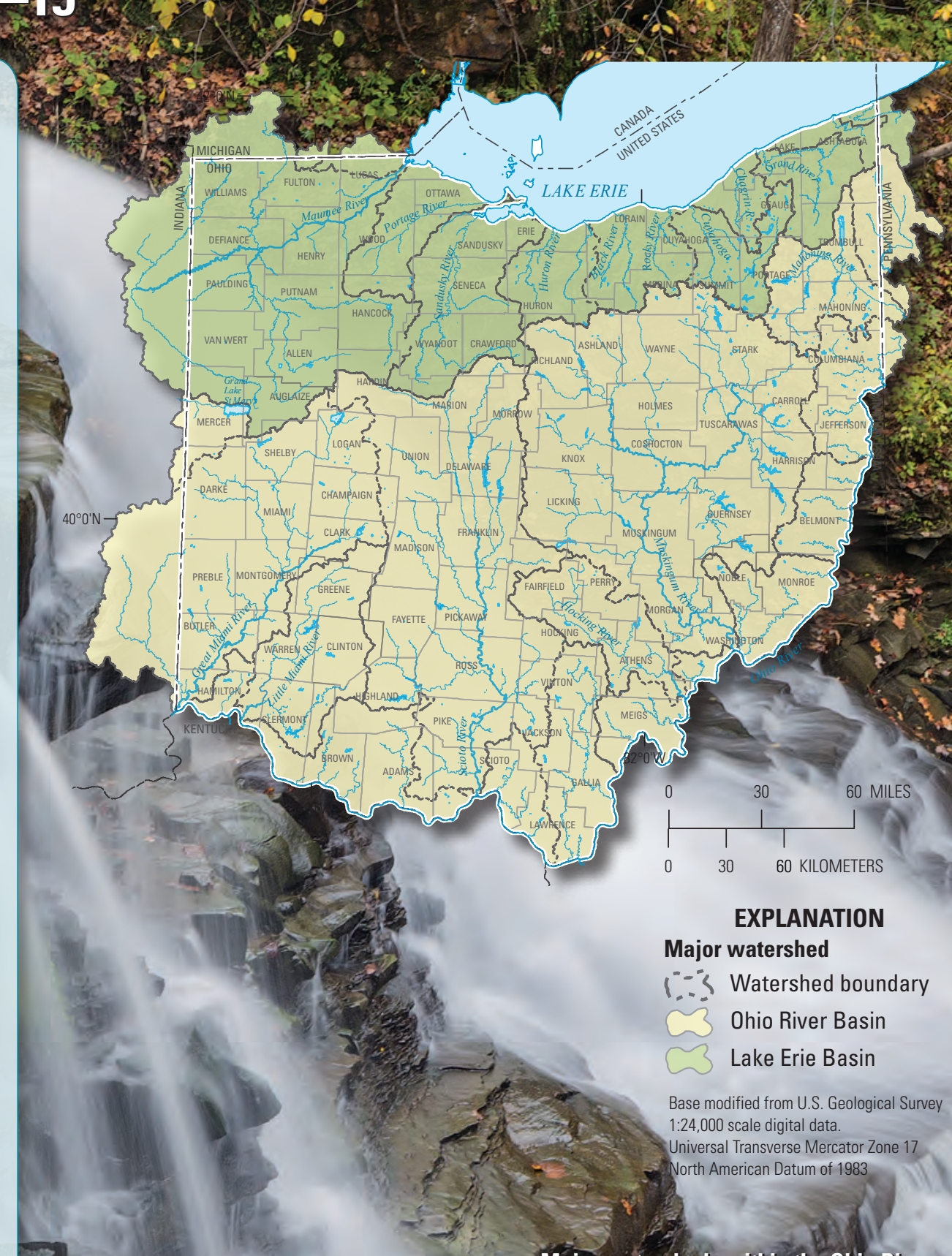
$\infty$

Major watersheds within the Ohio Ritver

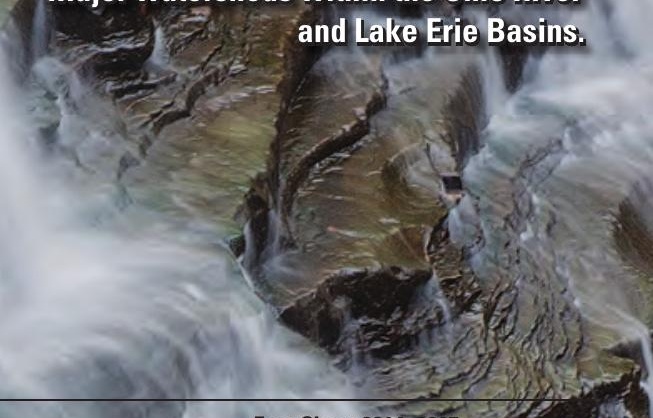



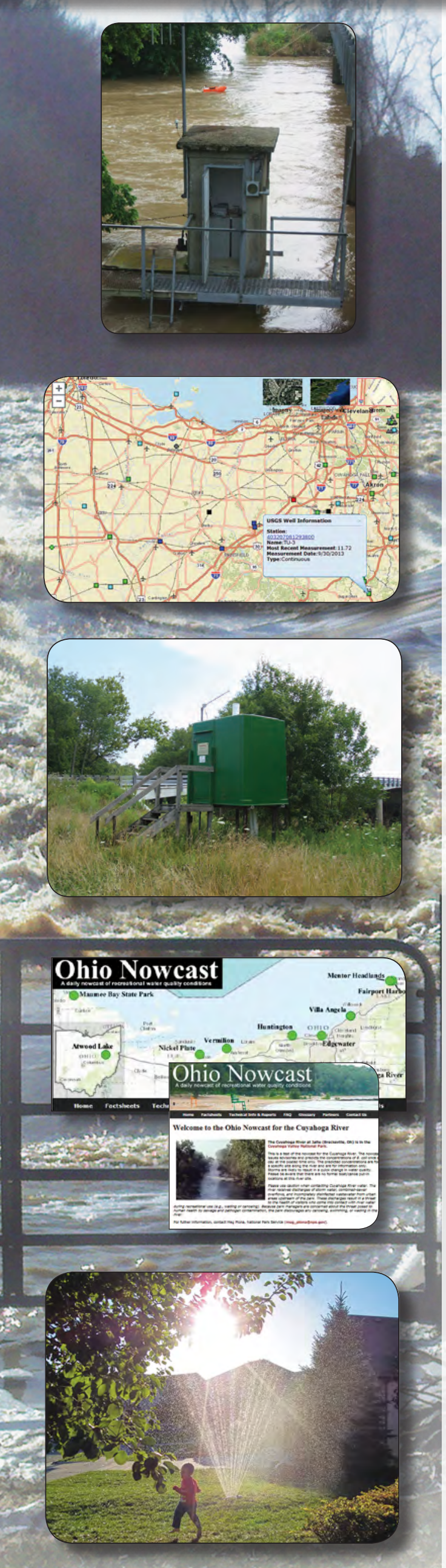

\section{Streamflow Data Available Online}

The USGS in Ohio - in cooperation with local, State, and Federal partners - operates about 240 streamgages, about 160 of which are used to compute streamflow. There are about 7,400 USGS streamgages nationwide; many of these gages provide real-time data in 15- to 60-minute increments and typically transmit the data to the Web every hour via satellite. These streamgages provide streamflow information for a wide variety of uses including flood prediction, water management and allocation, engineering design, research, operation of locks and dams, and recreational safety and enjoyment. In addition to these data, field-measurement data, streamflow statistics, and annual peak streamflows from each station are available on the Web through the National Water Information System (NWIS).

http://waterdata.usgs.gov/oh/nwis/rt

For more information, contact Thomas Harris, tharris@usgs.gov.

\section{Groundwater Data Available Online}

State and local agencies in Ohio (and to a limited extent, the USGS) collect, research, interpret, and disseminate groundwater data to characterize the groundwater resources of the State. To address these needs, the Ohio Department of Natural Resources (ODNR) and the Miami Conservancy District (MCD) monitor groundwater levels for more than 140 wells throughout Ohio. Personnel from the USGS Ohio Water Science Center and ODNR compile and publish water levels on the Groundwater Watch and NWIS Web sites.

http://groundwaterwatch.usgs.gov/statemap.asp? $s c=39 \& s a=O H$

For more information, contact Robert Darner, radarner@usgs.gov.

\section{Water-Quality Monitoring Network in Ohio}

The USGS operates a network of near-real-time water-quality monitoring stations that provide data for temperature, specific conductance, $\mathrm{pH}$, dissolved oxygen, and turbidity of surface water; the data are collected in 15- to 60-minute increments and typically are transmitted to the Web every hour via satellite. These data are needed for decision making regarding drinking water, water treatment, regulatory programs, recreation, healthy ecosystems, and public safety. Data are stored in the NWIS.

http://waterwatch.usgs.gov/wqwatch/

http://waterdata.usgs.gov/oh/nwis/current/?type=quality

For more information, contact Kimberly Shaffer, kshaffer@usgs.gov.

\section{Nowcast-Water-Quality Conditions at Beaches and a Recreational River}

Local agencies monitor water to measure the concentration of Escherichia coli (E. coli) - an indicator bacterium found in sewage and other animal wastes - to determine whether the water is safe for contact recreation such as swimming or canoeing. Conventional analytical methods can take 18 to 24 hours to yield results. To improve the timeliness and accuracy of recreational water-quality assessments, quick measurements, such as rainfall or water clarity, can be used to estimate the probability that E. coli exceeds safe levels. For example, the Ohio Nowcast is a system that provides near-real-time beach advisories to the public through use of quick measurements and predictive models; during 2014, Ohio Nowcast water-quality information was available for eight Lake Erie beaches and one recreational river site. In a study at 49 Great Lakes beaches, the USGS, in cooperation with many local and State agencies, found that predictive models overall performed better than the conventional methods to assess recreational water quality.

http://www.ohionowcast.info/index.asp; see also report at http://pubs.usgs.gov/sir/2013/5166/

For more information, contact Donna Francy,dsfrancy@usgs.gov.

\section{Ohio Water-Use Program}

Every 5 years since 1950, water-use data have been compiled and disseminated in Ohio as part of the USGS National Water-Use Information program. Current water-use categories include public supply, domestic, irrigation, livestock, aquaculture, industry, mining, and thermoelectric power. Water-use data are available by county and 8-digit Hydrologic Unit Codes.

http://oh.water.usgs.gov/water_use.html

For more information, contact Kimberly Shaffer, kshaffer@usgs.gov. 


\section{Crest-Stage Streamgage Network in Ohio}

Historically, small streams with drainage areas less than 100 square miles have been under represented in regional peak-flow analyses. To help fill this data gap, crest-stage gages were installed during 2001 at 18 sites throughout Ohio to augment the peak-flow record for smalldrainage-area streams. After enough peak-flow measurements have been collected at these sites, the statewide flood-frequency analysis can be updated to improve the estimation of peak flows.

http://oh.water.usgs.gov/crest-stage.html

For more information, contact Branden Vonins, blvonins@usgs.gov.

\section{Flood-Studies and Flood-Warning Systems Program}

This program employs hydrologic and hydraulic analyses to determine water-surface elevations associated with specific flood magnitudes at several points along a stream channel. The water-surface elevation data are used together with land-surface elevation data to determine and map the corresponding spatial extent of flood inundation. In some cases, libraries of flood-inundation maps are prepared for stream channels near USGS streamgages at which the National Weather Service (NWS) forecasts flood levels. In those cases, the NWS forecasts can be used in advance via map-based Web applications (for example, see http://wim.usgs.gov/ FIMI) to determine areas that are likely to flood at the forecasted levels. These studies and tools serve as a foundation for making science-based decisions to better manage flood risk and efforts to mitigate flood impacts.

http://water.usgs.gov/osw/flood_inundation/

For more information, contact Dave Straub,destraub@usgs.gov.

\section{StreamStats}

Ohio StreamStats is a Web-based Geographic Information System (GIS) application that allows users to easily obtain a variety of low-flow and peak-flow statistics; daily, monthly, and annual streamflow statistics; basin characteristics; and other information for ungaged stream sites in Ohio. Published statistics for gaged sites in the NWIS also are provided through the StreamStats map application. The StreamStats interface includes an assortment of analytical tools that are useful for water-resources planning and management.

http://water.usgs.gov/osw/streamstats/ohio.html

For more information, contact Greg Koltun,gfkoltun@usgs.gov.

\section{Assessing the Hydrological Effects of Potential Changes in Climate and Water Use in the Upper Scioto River Basin}

The central Ohio region is projected to grow by 450,000 people between 2005 and 2030 (Ohio Department of Development, 2003). The USGS is developing a rainfall-runoff model of the Upper Scioto River Basin to help water managers and planners assess whether existing and planned water-supply systems will be adequate to meet the region's future demand for water. This model will be used to estimate potential hydrologic effects of climate-change outcomes predicted by several climate-change models, and it will be instrumental for evaluating potential future alternative water-management practices.

For more information, contact Chad Ostheimer, ostheime@usgs.gov.

\section{Low-Flow Streamgage Network in Ohio}

Data on low-flow characteristics are used by water-resource managers for a variety of purposes, including water-supply planning, making decisions about wastewater-discharge and waterwithdrawal permits, and evaluating instream-flow requirements. The Ohio Water Science Center collects low-flow data throughout Ohio to expand the base of available information. The Ohio low-flow network consists of both continuous-record streamflow sites and sites where streamflow is measured only during low-flow periods.

http://oh.water.usgs.gov/low-flow_network.html

For more information, contact Joel Metzker,jmetzker@usgs.gov. 


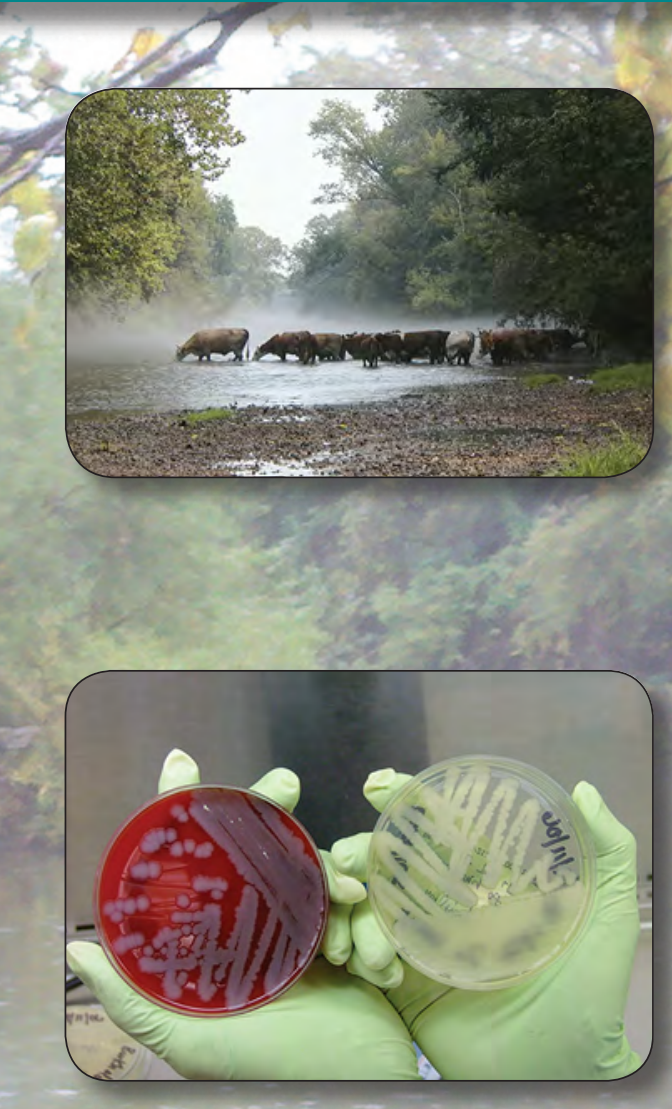

\section{Microbial Source Tracking}

The USGS Water Microbiology Laboratory in Columbus has been working with numerous agencies and USGS Water Science Centers to analyze water samples for microbial source tracking (MST) markers using the quantitative polymerase chain reaction (qPCR) method. Results from MST analyses help to characterize the effects of various sources of fecal contamination in a watershed. Currently, water samples can be analyzed for DNA markers that are associated with humans, cows and other ruminants, dogs, and waterfowl. In addition to MST marker analyses, other steps are generally taken as part of a multi-tiered approach to source tracking. These steps include conducting sanitary surveys, determining the distributions of bacterial indicators in the watershed, and understanding how hydrologic and meteorological processes affect the distributions of indicators and MST markers.

http://oh.water.usgs.gov/micro_index.htm

For more information, contact Chris Kephart, ckephart@usgs.gov.

\section{Testing Rapid Detection Methods for Drinking Water and Recreational Waters}

Rapid water-quality tests for microorganisms are needed to quickly ensure that water is safe for consumption or recreation. The USGS is testing and optimizing a rapid viability polymerase chain reaction (RV-PCR) method for the detection of viable (living) microorganisms that are potential biological warfare agents. Using a surrogate for Bacillus anthracis (the bacterium that causes anthrax), the results from the RV-PCR method are being compared to traditional culture methods. The USGS also has been developing and testing an immunomagnetic method that can provide $E$. coli and enterococci results in 2 hours rather than the conventional 18-24 hours for recreational waters.

http://oh.water.usgs.gov/micro_index.htm

For more information, contact Rebecca Bushon, rnbushon@usgs.gov.

\section{Modeling Aquatic Species Distributions on the Basis of Physical Habitat and Climate Change}

Gap analysis is a coarse-scale assessment of aquatic biodiversity and conservation, the results of which can be used to guide biological field studies and monitoring programs. Potential species distribution models were developed for 130 fish, 70 bivalve, and 17 native crayfish species on the basis of a physical habitat-based classification of the perennial streams in Ohio.

A more recent study has integrated fish-habitat classifications and associated fish-community data with downscaled (regional) climate predictions under different climate-change scenarios to identify vulnerable river systems and to project likely climate-driven changes to important fish species.

http://oh.water.usgs.gov/ohgap.htm

For more information, contact Alex Covert, sacovert@usgs.gov.

\section{Cyanobacteria and Toxins-Lake Erie and Ohio Inland Lakes}

In Ohio, local health officials and state agencies have identified the presence toxins associated with harmful algal blooms (HABs) caused by cyanobacteria during the summer and early fall seasons at recreational and water-supply lakes. The USGS, in cooperation with partner organizations, is monitoring recreational beaches and swimming areas in Ohio to better understand the link between cyanobacteria community structure, environmental and water-quality factors, and bloom toxicity. Samples are analyzed for physical water-quality characteristics, concentrations of nutrients and cyanotoxins, and phytoplankton abundance and community structure. Two new analytical methods will be tested for possible inclusion in an early warning system for toxin production: (1) chlorophyll and phycocyanin concentration measured by optical sensors and (2) cyanobacterial genetic structure, including the presence of toxin genes, determined with quantitative polymerase chain reaction (qPCR).

http://oh.water.usgs.gov/micro_projects_D5W86.htm

For more information, contact Donna Francy,dsfrancy@usgs.gov. 


\section{Low-Impact Development and Stormwater Best Management Practices}

Low-impact development (LID) is an approach to managing stormwater as near to its source as possible; this is accomplished by minimizing impervious surfaces and promoting more natural infiltration and evapotranspiration than is typically associated with developed areas. Stormwater best management practices (BMPs) are engineered attempts to decrease stormwater runoff and associated problems such as increased pollution and flooding in urban areas.

Chagrin River Watershed in Northeastern Ohio: Long-term hydrologic data were collected at two LID sites in northeastern Ohio to document their hydraulic characteristics.

Slavic Village, Cleveland: A groundwater network (20 wells) and weather stations are being used to gather data about two neighborhood block areas to better guide future green infrastructure.

Griggs Reservoir, Columbus: Hydrologic data are being collected to determine the effectiveness of recently installed BMPs to reduce stormwater runoff near Griggs Reservoir.

St. Francis, Cincinnati: A pilot project is ongoing to determine the effectiveness and viability of a pair of stepped rain gardens to reduce the quantity of stormwater runoff and improve water quality of parking lot runoff.

Cincinnati State Technical and Community College, Cincinnati: Hydrologic data are being collected for three stormwater BMPs to determine their effectiveness and viability for minimizing stormwater discharge to combined-sewer pipes.

http://oh.water.usgs.gov/bmps.html

For more information, contact Robert Darner, radarner@usgs.gov.

\section{Arsenic in Groundwater of Ohio}

Arsenic is odorless and tasteless and can enter drinking-water supplies from natural deposits in rock and soil. In some parts of Ohio, arsenic concentrations in groundwater have exceeded the arsenic drinking-water standard of 10 parts per billion that the U.S. Environmental Protection Agency has set to protect consumers from the effects of long-term, chronic exposure to arsenic (U.S. Environmental Protection Agency, 2012).

The USGS is investigating arsenic concentrations in water from domestic wells in southwestern and central Ohio as part of a broader effort to understand which areas in Ohio are most vulnerable to contamination from naturally occurring arsenic, as well as methane (a colorless, tasteless, and odorless gas that can be flammable and can displace oxygen in a confined space, causing asphyxiation). The USGS has also investigated the effectiveness of arsenic treatment methods in domestic wells.

http://arsenicinohiogroundwater.info/

For more information, contact Mary Ann Thomas, mathomas@usgs.gov.

\section{Long-Term Water-Level Monitoring Network, Geauga County, Ohio}

Residents of Geauga County rely almost exclusively on domestic and public-supply wells tapping groundwater as their source of drinking water. County planners are concerned that steady population growth, in combination with the predominance of groundwater use in the county, will result in water being withdrawn faster than it is recharged.This study involves monitoring groundwater levels in 31 wells across the county that are in four widely used aquifers. Knowledge of the magnitude and locations of groundwater declines in the county are needed to assist in planning for continued growth and conservation of groundwater resources.

Another project, which monitors water levels from a network in the vicinity of South Russell Village, Geauga County, is used to evaluate whether variations in groundwater levels are caused by annual variations in precipitation or residential and commercial development.

http://groundwaterwatch.usgs.gov/countymap.asp? $s a=O H \& c c=055$

For more information, contact Martha Jagucki,mjagucki@usgs.gov.



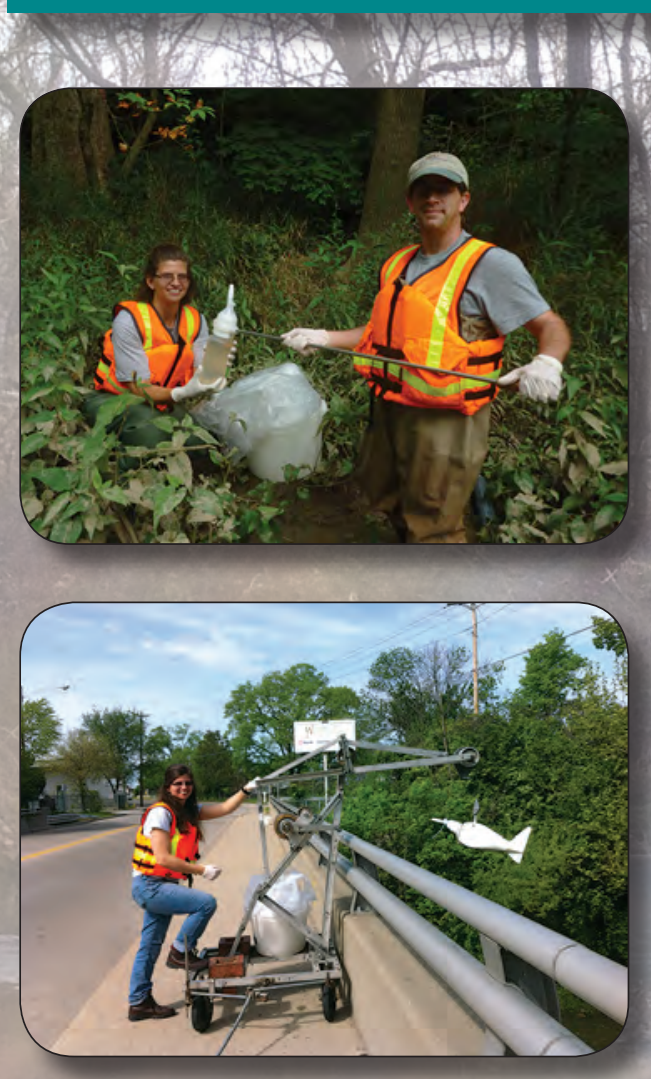

\section{Other USGS Resources}

Climate and Land-Use Change

http://www.usgs.gov/climate_landuse/

Core Science Systems (Mapping)

http://www.usgs.gov/core_science_systems/

Ecosystems

http://www.usgs.gov/ecosystems/

Energy and Minerals

http://www.usgs.gov/energy_minerals/

Environmental Health

http://www.usgs.gov/envirohealth/

Natural Hazards

http://www.usgs.gov/natural_hazards/

Water

http://www.usgs.gov/water/

\section{National Water-Quality Assessment (NAWOA) Program}

The program was established in 1991 to provide an understanding of water-quality conditions; whether conditions are getting better or worse over time; and how natural features and human activities affect those conditions. Regional and national assessments are possible because of a consistent study design and uniform methods of data collection and analysis. Monitoring data are integrated with geographic information on hydrological characteristics, land use, and other landscape features in models to extend water-quality understanding to unmonitored areas Local, State, Tribal, and national stakeholders use NAWQA information to design and implement strategies for managing, protecting, and monitoring water resources in many different hydrologic and land-use settings across the Nation.

\section{Current NAWQA activities at the Ohio Water Science Center}

Surface-Water Status and Monitoring Assessment: Long-term data collection at fixed (long-term) sites supports NAWQA's efforts to identify and understand water-quality trends, estimate loads, and develop large-scale transport models. Ohio surface-water activities include the collection of sediment and water-quality samples from the Maumee River at Waterville (USGS station 04193500). Periodically since 1994, samples have been collected from selected rivers in the Lake Erie Basin and the Great and Little Miami River Basins for the NAWQA Program.

http://waterdata.usgs.gov

For more information, contact Dennis Finnegan,dpfinneg@usgs.gov.

Ecological studies: include the collection of habitat, fish, algae, and macroinvertebratecommunity data. This type of data for Ohio can be found in the USGS ecological database BioData.

\section{https://aquatic.biodata.usgs.gov/}

For more information, contact Stephanie Janosy, sjanosy@usgs.gov.

Regional Stream-Quality Assessments: target water-resource issues specific to particular areas of the Nation, with a focus on water quality and ecological stressors.

During summer 2013, the Midwest Stream-Quality Assessment (MSQA) characterized contaminants, nutrients, suspended sediment, and ecological conditions at perennial-stream sites throughout the Corn Belt, including western Ohio. These results will be incorporated into statistical models to determine the effects of stressors on ecological communities and to allow prediction of water-quality conditions in other streams across the region.

http://water.usgs.gov/nawqa/studies/msqa/objectives.html

For more information, contact Daniel Button,dtbutton@usgs.gov.

NAWOA groundwater studies: in Ohio include collecting groundwater water-quality samples, measuring water levels, and assessing trends in a glacial aquifer. Three well networks in the glacial aquifer (consisting of both monitoring wells and domestic wells) are being used to collect data in urban areas, agricultural areas, and areas relatively undisturbed by human activities.

http://water.usgs.gov/nawqa/studies/praq/

For more information, contact Donna Runkle,dlrunkle@usgs.gov, or

Mary Ann Thomas, mathomas@usgs.gov.

\section{References Cited}

Ohio Department of Development, 2003, Office of Policy Research and Strategic

Planning, Population projections for Ohio and counties by age and sex, 2000 to 2030 ,

accessed July 23, 2012, at http://www.development.ohio.gov/research/

Reports_in_population_and_housing-Population_Projections.htm.

State of Ohio, 1994, Ohio's water Ohio's future - 1994 Final report: Governor's Blue Ribbon

Task Force on Water Resources Planning and Development, 31 p., accessed July 23, 2012, at

http://www2.ohiodnr.com/portals/soilwater/pdf/groundwater/Ohiowaterfuture.pdf.

U.S. Environmental Protection Agency, 2012, Arsenic in drinking water, accessed June 15, 2012, at http://waterepa.gov/lawsregs/rulesregs/.

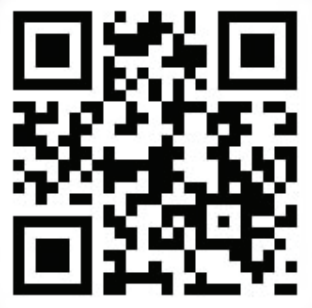

